\title{
ASSOCIATION BETWEEN RATIONAL USE OF ANTIBIOTICS, LENGTH OF STAY, AND DEATH, AMONG CHILDREN WITH PNEUMONIA IN SURAKARTA, CENTRAL JAVA
}

\author{
Miftakhul Ulum Mahfud, Titiek Hidayati, Kusbaryanto \\ Masters Program in Hospital Management, Universitas \\ Muhammadiyah Yogyakarta
}

\begin{abstract}
Background: Pneumonia is a major cause of morbidity and mortality in children under five. Optimal management of childhood pneumonia is challenging in settings where clinicians have limited information regarding the pathogen and drug resistance. This frequently results in unnecessary and poorly targeted antibiotic use. The irrational use of antibiotics may increase morbidity and mortality in children with pneumonia. This study aimed to examine the association between rational use of antibiotics, length of stay, and death, among children with pneumonia in Surakarta, Central Java.

Subjects and Method: This was a cross sectional study conducted in Surakarta, Central Java. A sample of 97 children with pneumonia was selected for this study by purposive sampling. The dependent variables were length of stay and death. The independent variable was the rational use of antibiotics. The data was obtained from medical record from 2014 to 2018. The data was analyzed by a multiple logistic regression.

Results: Contrary to expected hypothesis, bivariate analysis showed that rational use of antibiotics increased length of stay, and it was statistically significant $(\mathrm{OR}=4.95$; $95 \% \mathrm{Cl}=1.03$ to $23.72 ; \mathrm{p}=0.045)$. Supporting hypothesis, rational use of antibiotics decreased the risk of death due to pneumonia, although it was statistically non significant $(\mathrm{OR}=0.66 ; 95 \% \mathrm{Cl}=0.13$ to $3.37 ; \mathrm{p}=0.630)$.

Conclusion: This study resulted in inconsistent and inconclusive relationship between rational use of antibiotics, length of stay, and mortality in children with pneumonia.
\end{abstract}

Keywords: child pneumonia, rational use, antibiotics, length of stay, death

\section{Correspondence:}

Miftakhul Ulum Mahfud. Masters Program in Hospital Management, Universitas Muhammadiyah Yogyakarta. Email: ulummahfud@gmail.com. Mobile: o87715476909. 